\title{
Too-easy-to-lose Wall Street blues
}

\section{Stocks have been rallying and rates of both interest and inflation falling. Is the beginning of the end of the recession therefore in sight or is there more misery to come?}

Does the recent excitement on Wall Street and the rallies that have followed on other stock exchanges, mean that the long recession is coming to an end? It is natural that people should now be asking this hopeful question just as it is natural that a man lost in a desert should mistake refraction of light in the hot air near the ground for a pool of water. For if the people who make their livings by buying and selling stocks in commercial corporations now think it worthwhile to pay more for the commodities in which they trade, does that not imply that the outlook for US industry has improved? And does it not follow that industrial economies elsewhere will soon be on the mend? Unfortunately these conclusions, welcome though they would be, are unwarrantable. This is why.

Last week's rally on the stock exchanges followed from two significant developments in the United States - a modest but steady decline in the prevailing high interest rates and the government's success in persuading Congress, on the eve of its summer holidays, to enact a package of tax increases that will bring in an extra $\$ 98,300$ million over the next three years. If the financial community had waited a few days, it would no doubt have been further cheered to know that the annual rate of inflation in the United States has now fallen to 6.7 per cent. While each of these developments is a sign of progress in the right direction, neither of them implies that the end of the recession is at hand.

The decline of interest rates to below 14 per cent (when banks lend to each other or when people lend to the government) may save many industrial corporations from bankruptcy, but there is as yet no sign that corporations will seize this opportunity to invest in new plants and equipment. Why should they when they have to pay more than 17 per cent for the funds they borrow from the money market and the bank? A decline of interest rates is rather a sign that industry has virtually dropped out of the competition for people's savings, leaving the government as the only borrower of significance. This development is therefore more a sign that the recession has begun to bite than the promise that it is coming to an end.

On present form this will remain the case for some time to come. The package of tax increases half-heartedly proposed by the government and reluctantly swallowed by Congress will not do much to help. The government's deficit for the present financial year (which ends on 30 September) will be untouched at $\$ 110,000$ million or more. The tax increases now enacted will be effective only after 1 October, and are smaller than last year's tax reductions, also then coming into effect, and will not in themselves prevent the government's deficit actually increasing in future years. The hopeful sign and the only reason why Wall Street is excited is merely that the Reagan Administration appears at last to have recognized that it cannot run deficits on this scale without also running the economy into the ground. That a Republican administration should so lightly have thrown to the wind the traditional (and old-fashioned) Republican preoccupation with balanced budgets, remains a puzzle, while $\mathrm{Mr}$ Reagan's support for the proposed constitutional amendment that would compel future governments to balance their books is about as easily understood as a burglar's espousal of the calls of law and order.
The chances now are high that when the November elections are safely past, the President will make another attempt to behave as he says he should and will ask Congress to agree to a more substantial reduction of the social expenditure to which it has committed him. That will be a more bloody battle than that now won. The outcome cannot be foretold, but success will mean further misery for the growing army of the unemployed, now 9.7 per cent of the working population.

Meanwhile, there is precious little evidence that the transformation of the US industry has gone far enough to provide a foundation for future prosperity. As in most of Western Europe the privations of the recession have not yet made conventional manufacturing industry competitive with similar industries elsewhere, principally in Japan. Indeed, in the manufacture of steel and motor cars for example, the chief preoccupation is still to keep some semblance of these industries alive when there is no reason to suppose that they have an important place in the world. The time to celebrate the impending end of the recession will be when tangible signs of new industries emerging and of improved productivity in conventional industries are plain for all to see.

\section{A very different game \\ Can French success in boosting nuclear and space technology be repeated in electronics?}

A few weeks ago, the French government announced that it was to invest FF140,000 million ( $£ 12,000$ million) in the French electronics industry over the next three to five years - an apparently vast sum by all measures (see Nature 5 August, p.504). But now the dust is beginning to settle, it seems the amount of new gbiernment cash may not be so great. Some FF 90,000 million of the total was already due to be invested by the industry itself; and of the remaining FF50,000 million promised by the government (none of which has yet materialized) most can be accounted for by money already budgeted by the industry to be raised from the banks and other sources now nationalized.

So what is the great French electronics plan really all about? Central planning, it seems, despite President Mitterrand's insistence that the leadership of the nationalized industries would be free to manage their industries as they wished. What the President failed to emphasize was that the leadership would be chosen by the government.

So, for example, when the president of the newly-nationalized giant chemicals corporation, Rhône-Poulenc, felt obliged to resign recently (in protest against the "inconsistency" of government policy for his industry), the matter was dismissed by research and industry minister Jean-Pierre Chevènement in revealing terms. The state was in need of "good servants", he said. Jean Gandois, the resigning president, replied that he had found himself to be a "hostage" of the government.

With the leadership of much of industry in its pocket, therefore, the government must now manage industry something that the present British government would consider to be a logical impossibility. In France, the division between government and industry is not so sharp; the leaders of both 